\title{
Analisis Dan Perancangan Aplikasi Berbasis Web Untuk Pengelolaan Harga Pokok Produksi Menggunakan Metode Harga Pokok Proses
}

\author{
Devi Harisda ${ }^{1)}$, Magdalena Karismariyanti ${ }^{2)}$, Fitri Sukmawati ${ }^{3)}$ \\ 1, 2,3) Program Studi D3 Komputerisasi Akuntansi, Fakultas Ilmu Terapan Universitas Telkom \\ 1) deviharisda0@ gmail.com, ${ }^{2)}$ magdalena@ tass.telkomuniversity.ac.id, ${ }^{3)}$ fitri_unibi@yahoo.com
}

\begin{abstract}
Manufacturing of products incurred raw material costs, direct labor costs, and factory overhead costs, which could be used to determine the price of the product sold. On the contrary, the company, which manufactured thousands of toys and dolls monthly, did not have proper cost record. Production cost calculated by the average of total cost divided with a total of confirmed product. Hence, the production cost for each product could not be defined precisely. Based on the problems described, a web application was developed to manage the recording of transaction and automatically calculated the cost of production. This application's functionalities were able to manage purchasing activities, handing over raw materials to production, confirming finished goods, calculating production costs, posting journals and ledgers, and reporting of the cost of production. This application could help companies to calculate the unit cost. Based on a comparison between manual and application testing, it could be concluded that output in the application displayed an exact match from the manual. Thus, this web-based application was ready to be implemented in the company.
\end{abstract}

Keywords : cost of production; process costing; web based application

\section{PENDAHULUAN}

CV. XYZ merupakan badan usaha yang memproduksi berbagai jenis boneka. CV. XYZ melakukan produksi lebih banyak untuk stok dengan jumlah produksi rata per tahunnya. Tahun 2017, saat event hari raya Idulfitri, tahun baru, hari valentin dan liburan sekolah tiba, jumlah produksi meningkat sekitar 50\%-70\%. Pemilik CV. XYZ membeli bahan baku dari pemasok rata-rata dua kali dalam satu minggu. Proses produksi dilakukan setiap hari. Dalam menghitung biaya produksi perlu diketahui biaya-biaya yang terjadi didalamnya, untuk menghitung harga pokok produksi.

CV. XYZ tidak memiliki pencatatan dalam jumlah bahan baku yang tersisa dan yang digunakan untuk produksi. Begitu pula dengan biaya Overhead pabrik, dimana biaya Overhead pabrik digabung dengan Overhead toko. CV. XYZ tidak memperhitungkan nilai unit ekuivalen dalam mencari harga pokok per satuan. CV. XYZ membagi seluruh total biaya dengan produk yang selesai.

Nilai harga pokok produksi menjadi tidak tepat, saat penentuan biaya mengikuti harga taksiran dari harga produk dipasaran (Sari, 2018). Hal ini berdampak pada timbulnya ketidaksesuaian harga pokok satuan produk dengan biaya yang dikeluarkan saat memproduksi produk (Yuniar, Agung, \& Abdillah, 2016). Harga pokok proses dapat meningkat karena dipengaruhi oleh hilangnya produk selama proses produksi. Besaran biaya yang dikeluarkan oleh departemen, semakin meningkat, maka meningkatkan harga pokok proses (Afif \& Rahmawati, 2017).

Dalam penelitian terdahulu tentang harga pokok produksi digunakan metode process costing (Irwandi, Yuniar, \& Kotjoprayudi, 2017; Indarwati, kastaman, \& Samiji, 2017; Yuniar, Agung, \& Abdillah, 2016; Munifah, Widayanti, \& Yuniar, 2016) dan menggunakan metode job order costing (Irwandi, Yuniar, \& Kotjoprayudi, 2017). Metode ini diterapkan kedalam aplikasi akuntansi dengan fungsionalitas pencatatan transaksi untuk produksi 
memiliki persamaan dan perbedaan. Untuk proses pembelian bahan baku dilakukan secara tunai (Indarwati, kastaman, \& Samiji, 2017; Yuniar, Agung, \& Abdillah, 2016). Bill of Material (BOM) dibuat untuk mempermudah dalam produksi (Irwandi, Yuniar, \& Kotjoprayudi, 2017); terdapat jadwal produksi (Irwandi, Yuniar, \& Kotjoprayudi, 2017); menghitung unit ekuivalensi dan harga pokok per satuan (Irwandi, Yuniar, \& Kotjoprayudi, 2017; Indarwati, kastaman, \& Samiji, 2017; Yuniar, Agung, \& Abdillah, 2016; Munifah, Widayanti, \& Yuniar, 2016). Fungsionalitas lain adalah menghitung harga pokok produk jadi, harga pokok produk dalam proses dan membuat laporan biaya produksi (Irwandi, Yuniar, \& Kotjoprayudi, 2017; Indarwati, kastaman, \& Samiji, 2017; Yuniar, Agung, \& Abdillah, 2016; Munifah, Widayanti, \& Yuniar, 2016).

Penelitian ini menghasilkan aplikasi yang dapat perhitungan bahan yang digunakan dan pencatatan jumlah sisa bahan dapat dilakukan dengan cepat terkomputerisasi, pengelompokan biaya lebih tepat, sehingga dalam menentukan harga pokok per satuan yang tepat. Penelitian ini bertujuan mengimplementasikan perhitungan biaya produksi yang dapat menentukan harga pokok produksi dan aplikasi akuntansi. Metode process costing dipilih karena dapat digunakan dengan tepat untuk jenis perusahaan yang diteliti. Aplikasi ini dapat menyajikan jurnal, buku besar, dan laporan biaya produksi.

\section{TINJAUAN PUSTAKA}

\subsection{Akuntansi Biaya}

Akuntansi yang digunakan yaitu akuntansi biaya. Pada perusahaan manufaktur terdapat akuntansi biaya. Perusahaan dapat melakukan pengendalian internal sehingga dapat mengukur kinerja manajemen, dan memberikan informasi kepada pihak lain terkait aspek biaya operasi. Biaya yang terkait proses produksi, berdasarkan laporan harga pokok produksi, dapat digunakan sebagai acuan penentuan harga jual barang atau jasa Akuntansi biaya menentukan serta menyiapkan laporan harga pokok produksi. (Witjaksono, 2013).

\subsection{Harga Pokok Produksi}

"Harga pokok produksi adalah biaya barang yang dibeli untuk diproses sampai selesai, baik sebelum maupun selama periode akuntansi berjalan" (Prima, 2013). Penentuan harga pokok produksi ada dua metode, yaitu Metode Harga Pokok Pesanan dan Harga Pokok Proses.

Perbedaan dari kedua metode ini dapat dilihat berdasarkan kriteria pengumpulan biaya produksi. Harga pokok pesanan dihimpun per pesanan (Prima, 2013), sedangkan harga pokok proses dihimpun per departemen produksi per periode. Industri, yang memproduksi suatu produk tertentu secara berkelanjutan tanpa berdasarkan permintaan yang spesifik dari pelanggan, dapat menggunakan sistem penetepan harga pokok produk, yaitu harga pokok proses. Sistem harga pokok proses digunakan industri yang memiliki karakteristik sebagai berikut (Samryn, 2015).

a. Suatu jenis produk tunggal dihasilkan secara terus-menerus dalam waktu yang lama. Semua unit produk sifatnya identik.

b. Biaya-biaya dikumpulkan untuk tiap departemen secara periodik.

c. Laporan produksi dari departemen produksi merupakan dokumen kunci yang menunjukkan akumulasi dan disposisi biaya dalam tiap departemen.

d. Harga pokok per unit produk dihitung untuk tiap departemen dalam laporan produksi departemen secara periodik.

e. Biaya bahan pembantu diperlakukan sebagai biaya overhead pabrik. 
Sistem perhitungan biaya berdasarkan proses, terdapat tiga biaya yang dibebankan kepada pusat biaya, yaitu: bahan baku, tenaga kerja dan overhead pabrik. Contoh dari pusat biaya adalah departemen. Namun, pusat biaya bisa juga berupa pusat pemrosesan dalam satu departemen. Karakteristik produk yang diproduksi secara kontinu atau diproduksi massal dalam satu departemen dapat menggunakan perhitungan biaya dalam proses (Prima, 2013).

Tabel 1 Data Produksi dan Biaya

\begin{tabular}{|c|c|}
\hline \multicolumn{2}{|l|}{ Data Produksi dan Biaya } \\
\hline (tingkat penyelesaian $=100 \%)$ & Rp.5.000.000 \\
\hline (tingkat penyelesaian $=100 \%)$ & Rp.7.500.000 \\
\hline (tingkat penyelesaian $=50 \%)$ & Rp.11.250.000 \\
\hline$($ tingkat penyelesaian $=30 \%)$ & Rp.16.125.000 \\
\hline Total Biaya Produksi & Rp.39.875.000 \\
\hline \multicolumn{2}{|l|}{ Jumlah produk yang dihasilkan pada bulan tersebut yaitu : } \\
\hline Produk Jadi & $2.000 \mathrm{~kg}$ \\
\hline \multicolumn{2}{|l|}{ Jumlah produk dalam proses pada akhir bulan yaitu : } \\
\hline Produk dalam proses & $500 \mathrm{~kg}$ \\
\hline
\end{tabular}

Tabel 1 adalah contoh perhitungan dalam produksi make to stock dan memiliki satu departemen. Jumlah biaya yang terjadi akibat proses produksi (Mulyadi, 2015). Perhitungan harga pokok persatuan didapat dari hasil total biaya dibagi dengan unit ekuivalensi, dapat dilihat pada Tabel 2 sebagai berikut.

Tabel 2 Perhitungan Harga Pokok Per Satuan

\begin{tabular}{|c|c|c|c|}
\hline Unsur Biaya produksi & Total biaya & Unit ekuvalensi & $\begin{array}{l}\text { Biaya Produksi per } \\
\text { Satuan }\end{array}$ \\
\hline (1) & (2) & (3) & $(4)=(2) /(3)$ \\
\hline Bahan baku & Rp. $\quad 5.000 .000$ & 2.500 & Rp. \\
\hline Bahan penolong & Rp. $\quad 7.500 .000$ & 2.500 & 3.000 \\
\hline Tenaga kerja & Rp. 11.250 .000 & 2.250 & 5.000 \\
\hline Overhead pabrik & Rp. 16.125 .000 & 2.150 & 7.500 \\
\hline Total & Rp. 39.875 .000 & & Rp. 17.500 \\
\hline
\end{tabular}

Perhitungan harga pokok produk jadi dan persediaan produk dalam proses, menunjukkan perhitungan yang lebih spesifik antara produk yang sudah selesai dan dalam proses, dapat dilihat pada Tabel 3.

Tabel 3 Harga Pokok Produk Jadi dan Persediaan Produk dalam Proses

\begin{tabular}{|l|r|r|}
\hline \multicolumn{3}{|c|}{ Harga Pokok Produk Jadi dan Persediaan Produk dalam Proses } \\
\hline Harga Pokok produk Jadi & \multicolumn{2}{|c|}{ Rp.35.000.000 } \\
\hline Harga pokok persediaan produk dalam proses : & $\mathrm{Rp} .1 .000 .000$ & \\
\hline Biaya Bahan Baku (BBB) & $\mathrm{Rp} .1 .500 .000$ & \\
\hline Biaya Bahan Penolong (BBP) & $\mathrm{Rp} .1 .250 .000$ & \\
\hline Biaya Tenaga Kerja (BTK) & $\mathrm{Rp} .1 .125 .000$ & $\mathrm{Rp} .4 .875 .000$ \\
\hline Biaya Overhead Pabrik (BOP) & \multicolumn{3}{|c|}{ Rp.39.875.000 } \\
\hline \multicolumn{3}{|l|}{} \\
\hline
\end{tabular}

\section{METODE PENELITIAN}

Penelitian menggunakan pendekatan studi kasus, dimana CV. XYZ sebagai obyek penelitian merupakan perusahaan manufaktur mainan anak dan boneka. Data primer diperoleh dari wawancara dengan pemilik usaha sekaligus orang kunci yang menjalankan perusahaan. Selain wawancara, teknik pengumpulan data primer digunakan dalam bentuk observasi. Teknik ini digunakan untuk meneliti proses kerja, khususnya di bagian produksi. Daur hidup pengembangan perangkat lunak menggunakan model Waterfall. Waterfall terdiri dari tahap analisis yang dimodelkan dengan Use Case Diagram, tahap perancangan 
dimodelkan dengan Entity Relationship Diagram (ERD), tahap implementasi menjadi aplikasi berbasis web yang dibangun dengan PHP framework dan basis data MySQL, dan tahap pengujian.

\section{HASIL DAN PEMBAHASAN}

Membangun sebuah aplikasi, dibutuhkan perancangan sistem dan perancangan basis data. Use case Diagram dan ERD dipaparkan sebagai berikut.

\subsection{Use Case Diagram}

Use Case Diagram menjelaskan siapa yang menggunakan sistem dengan menggambarkan interaksi antara pengguna dengan sistem. Suatu ringkasan visual dari beberapa kasus penggunaan terkait dalam suatu sistem atau subsistem dapat diartikan sebagai Use Case diagram (Sukamto, 2013).

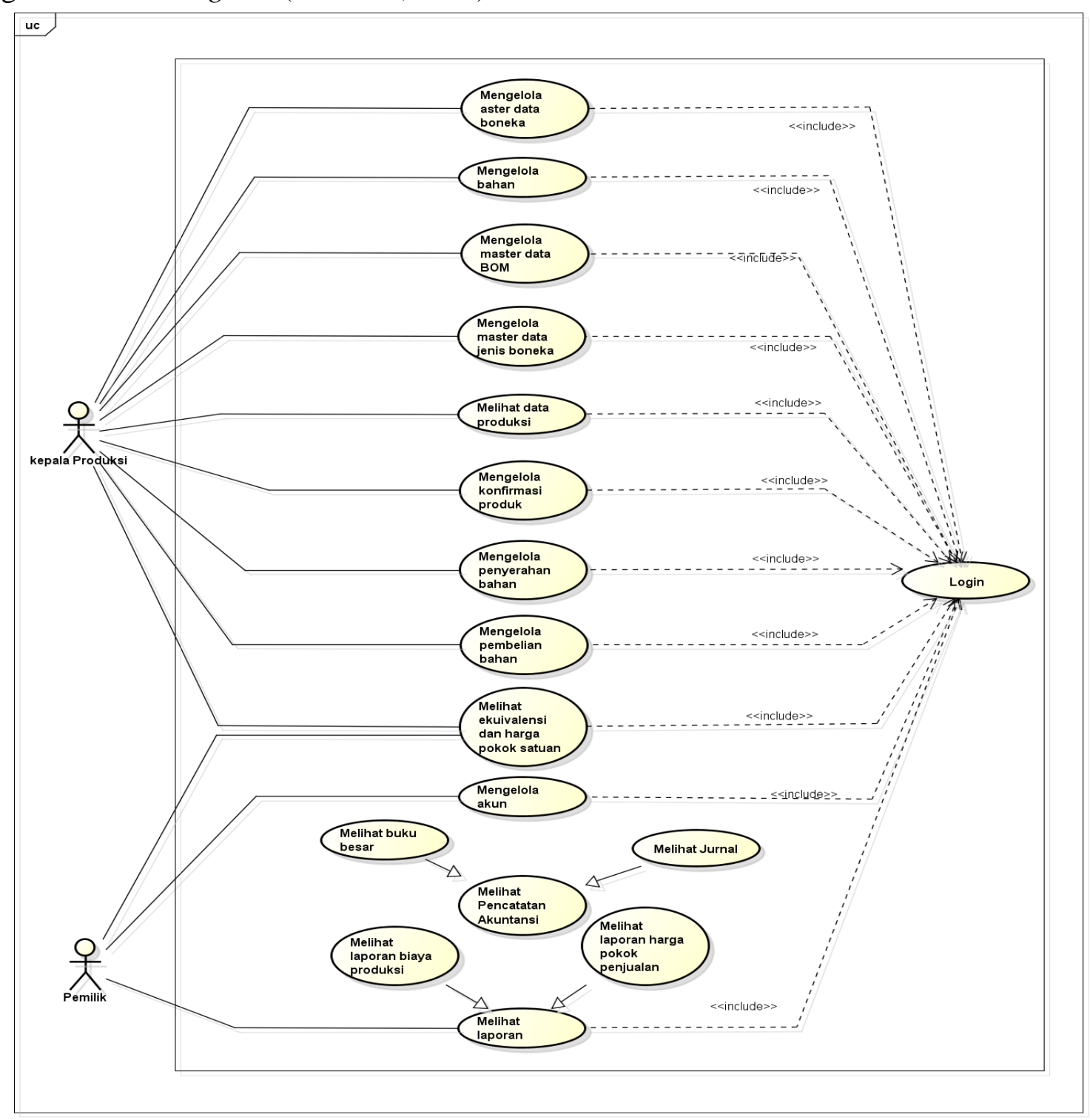

Gambar 1 Use Case Diagram 
Gambar 1 merupakan Use Case Diagram. Use Case Diagram representasi dari interaksi sistem yang menggambarkan fungsionalitas yang ada pada sistem dan siapa saja aktor yang berhak menggunakannya. Aktor kepala produksi berinteraksi dengan master data boneka, bahan, bom (bill of material), jenis boneka, produksi, pembelian, penyerahan bahan, konfirmasi produk selesai dan ekuivalensi harga pokok satuan, sedangkan aktor pemilik berinteraksi dengan fungsi akun, pencatatan akuntansi dan laporan.

\subsection{Entity Relation Diagram}

Entity Relationship Diagram (ERD), menggambarkan relasi antar entitas dari kasus yang diteliti. Simbol-simbol yang digunakan pada ERD menggunakan notasi Chen, yang dikembangkan oleh Peter Chen (Dermawan, 2013). ERP pada Gambar 2 akan menghasilkan 12 tabel.

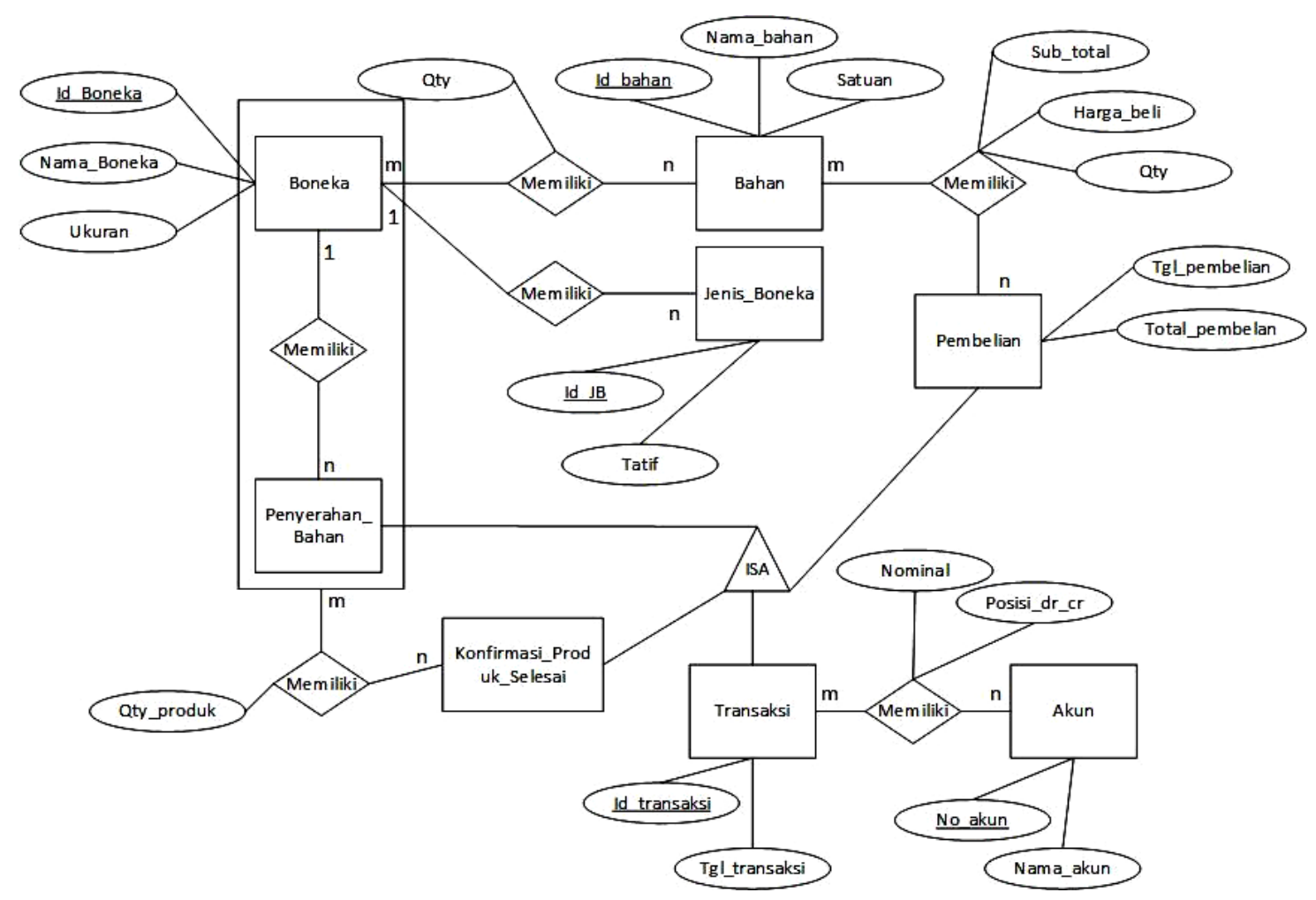

Gambar 2 Entity Relationship Diagram

\subsection{Implementasi dan Pengujian}

\subsubsection{Implementasi Aplikasi Berbasis Web}

Berdasarkan use case diagram, terdapat dua (2) pengguna yang akan mengakses sistem, sehingga diimplementasikan aplikasi berbasis web. Aplikasi dibangun dengan spesifikasi, yaitu: PHP framework Codeigniter Versi 2.2.5, basis data MySQL versi 5.0.11 dan web server Apache 3.2.2. Aplikasi berbasis web ini dijalankan dengan web browser dan dapat diakses dari komputer client. Pengujian perhitungan manual, dibandingkan dengan perhitungan hasil luaran aplikasi, digunakan untuk memvalidasi luaran yang akan dilihat pengguna. Tampilan aplikasi dapat dilihat pada Gambar 4, 5 dan 6. 


\subsubsection{Pengujian Manual}

Tabel 4 Kebutuhan Bahan Baku dan Bahan Penolong untuk Target Produksi Periode

Mei 2018

\begin{tabular}{|c|l|r|l|r|r|c|}
\hline Boneka & Ukuran & $\begin{array}{c}\text { Target } \\
\text { Produksi }\end{array}$ & $\begin{array}{c}\text { Nama } \\
\text { Bahan }\end{array}$ & Kebutuhan & \multicolumn{1}{c|}{$\begin{array}{c}\text { Total } \\
\text { kebutuhan }\end{array}$} & Keterangan \\
\hline $\mathbf{( 1 )}$ & $\mathbf{( 2 )}$ & $\mathbf{( 3 )}$ & $\mathbf{( 4 )}$ & \multicolumn{1}{c|}{$\mathbf{( 5 )}$} & $\mathbf{( 6 )}=\mathbf{( 3 )} \mathbf{x} \mathbf{( 5 )}$ & $\mathbf{( 7 )}$ \\
\hline Teddy bear & Besar & 1.087 & kapas & $3 \mathrm{gr}$ & 3.261 & Bahan Baku \\
\hline & & & kain & 4 meter & 4.348 & Bahan Baku \\
\hline & & & benang & 8 meter & 8.696 & Bahan Penolong \\
\hline & & & lem & $1 \mathrm{ml}$ & 1.087 & Bahan Penolong \\
\hline & & & mata & 2 buah & 2.174 & Bahan Penolong \\
\hline & & & hidung & 1 buah & 1.087 & Bahan Penolong \\
\hline Panda & Sedang & 500 & kapas & $2 \mathrm{gr}$ & 1.000 & Bahan Baku \\
\hline & & & kain & 1 meter & 500 & Bahan Baku \\
\hline & & & benang & 6 meter & 3.000 & Bahan Penolong \\
\hline & & & lem & $1 \mathrm{ml}$ & 500 & Bahan Penolong \\
\hline & & & mata & 2 buah & 1.000 & Bahan Penolong \\
\hline & & & hidung & 1 buah & 500 & Bahan Penolong \\
\hline
\end{tabular}

Pengujian manual dalam penelitian ini dilakukan dengan membuat kasus uji. Tabel 4 memperlihatkan data jumlah target produksi masing-masing boneka untuk bulan Mei 2018. Total kebutuhan bahan baku yang akan digunakan untuk semua boneka, diperoleh dari pengkalian kolom kebutuhan dikali target produksi.

Tabel 5 Jumlah Kebutuhan Bahan

\begin{tabular}{|l|r|c|c|}
\hline \multicolumn{1}{|c|}{ Nama Bahan } & Jumlah Kebutuhan & Satuan & Keterangan \\
\hline Kapas & $\mathbf{( 2 )}$ & $\mathbf{( 3 )}$ & $\mathbf{( 4 )}$ \\
\hline Kain & 4.261 & gr & Bahan Baku \\
\hline Benang & 4.848 & meter & Bahan Baku \\
\hline Lem & 11.696 & meter & Bahan Penolong \\
\hline Mata & 1.587 & ml & Bahan Penolong \\
\hline Hidung & 3.174 & buah & Bahan Penolong \\
\hline
\end{tabular}

Tabel 5 merupakan jumlah kebutuhan bahan keseluruhan. Jumlah kebutuhan, pada table 5 kolom (2), diperoleh dari total target produksi, pada table 4 kolom (5), yaitu 3.261, kebutuhan kapas untuk boneka Teddy bear, ditambah 1.000 kebutuhan kapas untuk boneka panda, sehingga total menjadi 4.261 untuk bahan kapas.

Tabel 6 Perhitungan Pembelian Ke-1

\begin{tabular}{|c|l|c|r|r|}
\hline Tgl Pembelian & Nama Bahan & Jumlah Bahan & Harga Satuan (Rp) & \multicolumn{1}{c|}{ Subtotal } \\
\hline $\mathbf{( 1 )}$ & \multicolumn{1}{|c|}{$(\mathbf{2})$} & $\mathbf{( 3 )}$ & $\mathbf{( 4 )}$ & $\mathbf{( 5 )}=\mathbf{( 3 )} \mathbf{x}(\mathbf{4})$ \\
\hline $1-5-2018$ & kapas & 3.500 & 3.000 & Rp. 10.500 .000 \\
\hline $1-5-2018$ & kain & 4.500 & 5.000 & Rp. 22.500 .000 \\
\hline $1-5-2018$ & benang & 9.000 & 100 & Rp. 900.000 \\
\hline $1-5-2018$ & lem & 1.000 & 100 & Rp. 100.000 \\
\hline $1-5-2018$ & mata & 2.000 & 500 & Rp. 1.000 .000 \\
\hline $1-5-2018$ & hidung & 1.000 & 500 & Rp.500.000 \\
\hline \multicolumn{4}{|r}{} \\
\hline
\end{tabular}

Pembelian bahan pada tanggal 1 Mei 2018 dapat dilihat pada Tabel 6 dengan data jumlah dan harga satuan setiap bahannya. Total Pembelian pada tanggal tersebut sebesar Rp. 35.500.000. Data penyerahan bahan pada tanggal yang sama dapat dilihat pada Tabel 8. Jumlah bahan yang tersedia di Gudang Pembelian, pada Tabel 7 kolom (3), diserahkan sebagian ke bagian produksi dengan jumlah bahan yang diserahkan pada Tabel 7 kolom (4). Jumlah bahan yang diserahkan ditargetkan untuk dapat menghasilkan 1.000 buah 
boneka Teddy Bear. Bahan baku yang diserahkan untuk proses produksi sebesar Rp. 29.000.000, yaitu sesuai dengan keterangan bahan baku pada Tabel 5 .

Tabel 7 Perhitungan Penyerahan Bahan Ke-1

\begin{tabular}{|c|c|c|c|c|c|c|}
\hline $\begin{array}{l}\text { Nama } \\
\text { bahan }\end{array}$ & Kebutuhan & $\begin{array}{l}\text { Jumlah } \\
\text { bahan }\end{array}$ & $\begin{array}{c}\text { Jumlah } \\
\text { bahan yang } \\
\text { diserahkan }\end{array}$ & $\begin{array}{l}\text { Jumlah yang } \\
\text { diserahkan }\end{array}$ & $\begin{array}{c}\text { Nama } \\
\text { boneka } \\
\text { (target } \\
\text { diproduksi) }\end{array}$ & $\begin{array}{c}\text { Jumlah } \\
\text { boneka } \\
\text { (masuk } \\
\text { produksi) }\end{array}$ \\
\hline (1) & (2) & (3) & (4) & $\begin{array}{c}(5)=(4) \times \text { Tabel } 6 \\
(4)\end{array}$ & $(6)$ & (7) \\
\hline kapas & $3 \mathrm{gr}$ & 3.261 & 3.000 & Rp. 9.000 .000 & \multirow{6}{*}{ Teddy bear } & \multirow{6}{*}{1.000} \\
\hline kain & 4 meter & 4.348 & 4.000 & Rp. 20.000.000 & & \\
\hline benang & 8 meter & 6.000 & 8.000 & Rp. 800.000 & & \\
\hline lem & $1 \mathrm{ml}$ & 1.087 & 1.000 & Rp. 100.000 & & \\
\hline mata & 2 buah & 2.174 & 2.000 & Rp. 1.000 .000 & & \\
\hline hidung & 1 buah & 1.087 & 1.000 & Rp. 500.000 & & \\
\hline
\end{tabular}

Tanggal 4 Mei dilakukan kembali pembelian bahan dengan total pembelian sebesar Rp.23.633.800 dapat dilihat pada tabel 8. Pada tanggal yang sama, data jumlah bahan untuk penyerahan bahan yang ke dua dapat dilihat pada Tabel 9.

Tabel 8 Perhitungan Pembelian Ke-2

\begin{tabular}{|c|c|c|c|c|}
\hline Tgl Pembelian & Nama Bahan & Jumlah & Harga Satuan & Subtotal \\
\hline (1) & $(2)$ & (3) & (4) & $(5)=(3) \times(4)$ \\
\hline $4-5-2018$ & kapas & 2.200 & 3.000 & Rp.6.600.000 \\
\hline $4-5-2018$ & kain & 3.100 & 5.000 & Rp.15.500.000 \\
\hline $4-5-2018$ & benang & 5.696 & 100 & Rp.569.600 \\
\hline $4-5-2018$ & lem & 837 & 100 & Rp.83.700 \\
\hline $4-5-2018$ & mata & 1.174 & 500 & Rp.587.000 \\
\hline $4-5-2018$ & hidung & 587 & 500 & Rp.293.500 \\
\hline \multicolumn{4}{|l|}{ Total Pembelian } & Rp.23.633.800 \\
\hline
\end{tabular}

Tabel 9 Penyerahan Bahan Ke-2

\begin{tabular}{|c|c|c|c|c|c|c|}
\hline $\begin{array}{l}\text { Nama } \\
\text { bahan }\end{array}$ & Kebutuhan & $\begin{array}{l}\text { Jumlah } \\
\text { bahan }\end{array}$ & $\begin{array}{c}\text { Jumlah } \\
\text { bahan yang } \\
\text { diserahkan }\end{array}$ & $\begin{array}{l}\text { Jumlah yang } \\
\text { diserahkan }\end{array}$ & $\begin{array}{c}\text { Nama } \\
\text { boneka } \\
\text { (target } \\
\text { diproduksi) }\end{array}$ & $\begin{array}{c}\text { Jumlah } \\
\text { boneka } \\
\text { (masuk } \\
\text { produksi) }\end{array}$ \\
\hline (1) & (2) & (3) & (4) & $\begin{array}{c}(5)=(4) x \\
\text { Tabel } 8(4)\end{array}$ & (6) & (7) \\
\hline kapas & $3 \mathrm{gr}$ & 4.200 & 261 & Rp. 783.000 & \multirow{6}{*}{ Teddy Bear } & \multirow{6}{*}{87} \\
\hline Kain & 4 meter & 5.600 & 348 & Rp. 1.740 .000 & & \\
\hline benang & 8 meter & 6.000 & 696 & Rp. 69.600 & & \\
\hline Lem & $1 \mathrm{ml}$ & 1.087 & 87 & Rp. 8.700 & & \\
\hline Mata & 2 buah & 2.174 & 174 & Rp. 87.000 & & \\
\hline hidung & 1 buah & 1.087 & 87 & Rp. 43.500 & & \\
\hline kapas & $2 \mathrm{gr}$ & 1.000 & 1.000 & Rp. 3.000.000 & \multirow{6}{*}{ Panda } & \multirow{6}{*}{500} \\
\hline Kain & 1 meter & 500 & 500 & Rp. 2.500 .000 & & \\
\hline benang & 6 meter & 3.000 & 3.000 & Rp. 300.000 & & \\
\hline Lem & $1 \mathrm{ml}$ & 500 & 500 & Rp. 50.000 & & \\
\hline Mata & 2 buah & 1.000 & 1.000 & Rp. 500.000 & & \\
\hline hidung & 1 buah & 500 & 500 & Rp. 250.000 & & \\
\hline
\end{tabular}

Data penyerahan bahan yang akan dilakukan pada tanggal yang sama dapat dilihat pada Tabel 9. Jumlah bahan yang diserahkan, kolom (4), diberikan kepada bagian produksi. Bahan baku yang diserahkan untuk proses produksi dicatat dalam jurnal sesuai dengan nama boneka, yaitu sebesar Rp. 2.523.000 (Rp. 783.000 ditambah Rp. 1.740.000) dan Rp. 5.500.000 (Rp. 3.000.000 ditambah Rp. 2.500.000). 
Tabel 10 Konfimasi Produk Selesai

\begin{tabular}{|c|c|c|c|c|c|c|}
\hline $\begin{array}{c}\text { Nama } \\
\text { boneka }\end{array}$ & $\begin{array}{c}\text { Target } \\
\text { boneka } \\
\text { per } \\
\text { periode }\end{array}$ & $\begin{array}{c}\text { Jumlah } \\
\text { boneka } \\
\text { (masuk } \\
\text { produksi) }\end{array}$ & $\begin{array}{c}\text { Total } \\
\text { boneka } \\
\text { selesai } \\
\text { diproduksi }\end{array}$ & $\begin{array}{c}\text { Total boneka } \\
\text { dalam } \\
\text { produksi }\end{array}$ & $\begin{array}{c}\text { Tarif } \\
\text { Upah }\end{array}$ & Total BTKL \\
\hline $\mathbf{( 1 )}$ & $(\mathbf{2})$ & $(\mathbf{3})$ & $\mathbf{( 4 )}$ & $\mathbf{( 5 ) = ( 3 ) - ( 4 )}$ & $\mathbf{( 6 )}$ & $\mathbf{( 7 ) = ( 4 ) \times ( 6 )}$ \\
\hline Teddy Bear & 1.087 & 1,087 & 450 & 637 & Rp. 10.000 & Rp. 4.500 .000 \\
\hline
\end{tabular}

Konfirmasi produk selesai menghasilkan biaya overhead pabrik (BOP) dan biaya tenaga kerja (BTKL). Konfirmasi produk selesai dilakukan pada akhir periode (atau hari) pada saat waktu produksi berakhir, dengan cara melaporkan jumlah boneka yang selesai diproduksi. Boneka Teddy Bear yang ditargetkan pada Periode Mei 2018 sebanyak 1.087 buah. Setelah dilakukan dua kali penyerahan bahan, diperoleh jumlah bahan baku yang telah diserahkan dapat memproduksi sebanyak 1.087 buah boneka, yang terdiri dari 1.000 buah boneka Tabel 7 dan 87 buah boneka dari Tabel 9. Pada tanggal 6 Mei, dikonfirmasi produk selesai sebanyak 450 buah boneka, dari 637 buah boneka berdasarkan bahan yang telah diserahkan ke bagian produksi. Data dapat dilihat pada Tabel 10.

\begin{tabular}{|c|c|c|}
\hline \multicolumn{3}{|c|}{$\begin{array}{c}\text { CV. XYZ } \\
\text { LAPOR_AN BIAYA PRODUKST } \\
\text { BONEKA TEDDY BEAR } \\
\text { BULAN MIEI } 2018\end{array}$} \\
\hline \multicolumn{3}{|l|}{ Data Produlssi } \\
\hline Dimasukkan dalam proses & & $\underline{0 \text { bonelca }}$ \\
\hline Produk jadi yang ditransfer ke Gudang & & $63 \overline{7 \text { boneka }}$ \\
\hline Produk dalam proses akhir & & 450 bonelca \\
\hline Jumlah produk yang dihasilkcan & & $1 . \overline{087 \text { bonelca }}$ \\
\hline \multicolumn{3}{|l|}{ Biaya yang dibebankan dalam bulan Mei 2018} \\
\hline & Total & Per Boneka \\
\hline $\begin{array}{r}\text { Biaya Bahan Baku } 1.087 \text { buah @ (Rp. } 3.000 \times 3 \\
+ \text { Rp. } 5.000 \times 4)\end{array}$ & Rp. $\overline{31.523 .000}$ & Rp. 29.000 \\
\hline \multicolumn{3}{|l|}{ Biaya Overhead Pabrik } \\
\hline $\begin{array}{l}\text { Biaya Listrik } 1.087 \text { buah @ } 0.025 \% \text { x Rp.200.000 } \\
\text { Biaya Bahan Penolong }\end{array}$ & 54.350 & Rp. \\
\hline Benang $\quad 1.087 \mathrm{buah} @(\mathrm{Rp} .100 \mathrm{x} 8)$ & 869,600 & Rp. 800.00 \\
\hline 1.087 buah $@(\mathrm{Rp} .100 \mathrm{x} 1)$ & 108,700 & Rp. 100.00 \\
\hline 1.087 buah $@(\mathrm{Rp} .500 \times 2)$ & $1,087,000$ & Rp.1,000.00 \\
\hline Hidung $\quad 1.087$ buah @ (Rp. $500 x$ 1) & Rp. $\quad 543.500$ & Rp. $\quad 500.00$ \\
\hline Total Biaya Overhead Pabrit & Rp. 2.663.150 & Rp. 2.450 \\
\hline Biaya Tenaga Kerja $\quad 1.087$ buah @ Rp. 10.000 & Rp. $10,870,000$ & Rp. 10.000 \\
\hline Jumlah & Rp. 45.056 .150 & Rp. 41.450 \\
\hline \multicolumn{3}{|l|}{$\begin{array}{l}\text { Perhitungan Biaya: } \\
\text { Harga Pokok Produk Jadi yang ditransfer ko Gudang }\end{array}$} \\
\hline 637 boneka @ Rp. 41.450 & & Rp. 26.403 .650 \\
\hline \multicolumn{3}{|l|}{ Harga Pokok Persediaan Produk dalam Proses A.khir: } \\
\hline $\begin{array}{r}\text { Biaya Bahan Baku BBB450 buah @ (Rp. } 3.000 \times 3 \\
+ \text { Rp. } 5.000 \times 4)\end{array}$ & 13.050 .000 & \\
\hline \multicolumn{3}{|l|}{ Biaya Overhead Pabrik } \\
\hline $\begin{array}{l}\text { Biaya Listrik } 450 \text { buah @ } 0.025 \% \pi \mathrm{Rp} .200 .000 \\
\text { Biaya Bahan Penolong }\end{array}$ & 22.500 & \\
\hline Benang 450 buah @ (Rp. $100 \times 8$ ) & 360.000 & \\
\hline 450 buah @ (Rp. $100 \times 1)$ & 45.000 & \\
\hline $\begin{array}{l}450 \text { buah @ (R.p. } 500 \times 2) \\
450 \text { buah @ (Rp. } 500 \times 1)\end{array}$ & $\begin{array}{l}450.000 \\
225.000\end{array}$ & \\
\hline Total Biaya Overhead Pabrik BOP & 1.102 .500 & \\
\hline Biaya Tenaga Kerja BTKL 450 buah @ Rp. 10.000 & 4.500 .000 & \\
\hline & & Rp. $18,652,500$ \\
\hline Jumlah biaya produkai yang dibebankcan & & Rp. $45,056,150$ \\
\hline
\end{tabular}

Gambar 3 Laporan Biaya Produksi Boneka Teddy Bear 
Total biaya overhead pabrik (BOP) didapat dari total yang diterima dari persentase riwayat pembayaran beban pada bulan Mei 2018. Biaya listrik berdasarkan tagihan listrik satu Gedung adalah Rp. 200.000, kemudian berdasarkan riwayat pemakaian listrik khusus pada area produksi adalah $0.025 \%$ dari tagihan listrik akan menjadi BOP Biaya listrik per boneka. Berikut ini adalah perhitungan BOP untuk boneka Teddy Bear dengan konfirmasi produk selesai sebanyak 450 buah boneka (Tabel 11). Laporan biaya produksi pada Gambar 3, menunjukkan Harga Pokok Per Satuan (Per Boneka) sebesar Rp. 41.450 dengan Harga Pokok Proses (atau Harga Pokok Persediaan Produk dalam Proses Akhir) untuk 450 buah boneka, yaitu sebesar Rp. 18,652,500.

Jurnal umum dapat dilihat pada Tabel 11. Jurnal ditampilkan untuk beberapa transaksi sesuai terjadinya transaksi

Tabel 11 Jurnal Umum

\begin{tabular}{|c|c|c|c|c|}
\hline Tgl & Nama Akun & Ref & Debit & Kredit \\
\hline \multirow[t]{3}{*}{$1 \mathrm{Mei}$} & Persediaan Bahan Baku & 118 & Rp.35.500.000 & \\
\hline & Kas & 111 & & Rp.35.500.000 \\
\hline & (Pembelian ke-1) & & & \\
\hline \multirow[t]{3}{*}{$1 \mathrm{Mei}$} & BDP-BBB & 113 & Rp.29.000.000 & \\
\hline & Persediaan Bahan Baku & 118 & & Rp.29.000.000 \\
\hline & (Penyerahan BBB Ke-1) & & & \\
\hline \multirow[t]{3}{*}{$6 \mathrm{Mei}$} & BDP-BTKL & 114 & Rp. 4.500 .000 & \\
\hline & Beban Upah & 513 & & Rp.4.500.000 \\
\hline & (Konfirmasi produk selesai) & & & \\
\hline \multirow[t]{4}{*}{$6 \mathrm{Mei}$} & BDP-BOP & 115 & Rp.1.102.500 & \\
\hline & Beban Listrik & 512 & & Rp.22.500 \\
\hline & Persediaan Bahan Penolong & 112 & & Rp.1.080.000 \\
\hline & (Konfirmasi produk selesai) & & & \\
\hline \multirow[t]{5}{*}{$6 \mathrm{Mei}$} & Persediaan Produk Jadi & 116 & Rp.18.652.500 & \\
\hline & BDP-BBB & 113 & & Rp.13.050.000 \\
\hline & BDP-BTKL & 114 & & Rp.4.500.000 \\
\hline & BDP-BOP & 115 & & Rp.1.102.500 \\
\hline & (Konfirmasi produk selesai) & & & \\
\hline \multirow[t]{5}{*}{$6 \mathrm{Mei}$} & Persediaan Dalam Proses & 117 & Rp.26.403.650 & \\
\hline & BDP-BBB & 113 & & Rp.18.473.000 \\
\hline & BDP-BTKL & 114 & & Rp.6.370.000 \\
\hline & BDP-BOP & 115 & & Rp.1.560.650 \\
\hline & (Konfirmasi produk selesai) & & & \\
\hline
\end{tabular}

\subsubsection{Pengujian Aplikasi}

Sesuai dengan pengujian manual yang dilakukan sebelumnya, maka dilakukan proses pengujian aplikasi untuk membandingkan hasilnya dengan pengujian manual sebelumnya. 


\begin{tabular}{llll} 
& & BAHAN BAKU & \\
\hline Kode Bahan & Nama Bahan & Sisa Yang Tersedia & Jumlah yang diserahkan \\
\hline BH1 & kapas & 500 & 3000 \\
\hline BH2 & kain & 500 & 4000 \\
\hline BH3 & benang & 1000 & 8000 \\
\hline BH4 & lem & 0 & 1000 \\
\hline BH5 & Mata & 0 & 2000 \\
\hline BH6 & hidung & 0 & 1000 \\
\hline
\end{tabular}

Gambar 4 Pengujian Proses Aplikasi Daftar Penyerahan Bahan

Gambar 4 merupakan daftar penyerahan bahan yang dilakukan, untuk melihat jumlah bahan yang telah digunakan dan bahan yang tersisa, sesuai dengan pengujian manual pada Tabel 8. Gambar 5 merupakan data konfirmasi produk selesai, sesuai dengan pengujian manual pada Tabel 11 dan Gambar 3. Informasi yang didapatkan adalah terdapat biaya overhead pabrik (BOP) dan biaya tenaga kerja langsung (BTKL). Hasil dari Laporan Biaya Produksi, Gambar 6, memperlihatkan implementasi harga pokok proses.

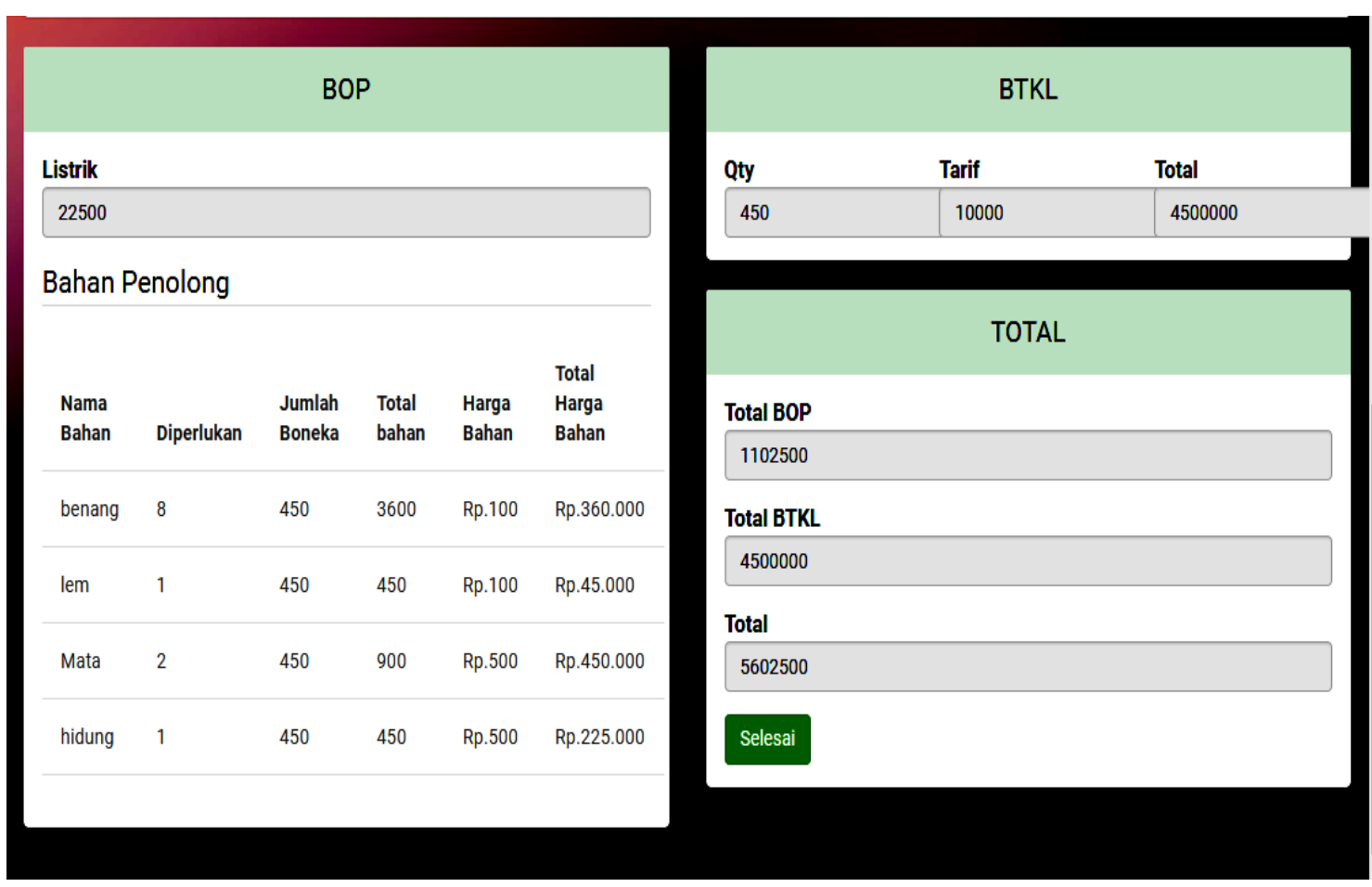

Gambar 5. Konfirmasi Produk Selesai 


\begin{tabular}{|c|c|c|c|}
\hline \multicolumn{4}{|c|}{ LAPORAN BIAYA PRODUKSI } \\
\hline \multicolumn{4}{|c|}{$\begin{array}{c}\text { CV XYZ } \\
\text { Laporan Biaya Produksi } \\
\text { Mei } 2018\end{array}$} \\
\hline \multicolumn{4}{|l|}{ Data Produksi } \\
\hline Dimasukkan dalam proses & & & 1.087 \\
\hline Produk jadi yang ditransfer ke gudang & & & 637 \\
\hline Produk dalam proses akhir & & & $\underline{450}$ \\
\hline Jumlah produk yang dihasilkan & & & 1.087 \\
\hline \multicolumn{4}{|l|}{ Biaya yang dibebankan } \\
\hline & Total & Per & 3oneka \\
\hline Biaya Bahan Baku & Rp. 31.523.000 & & 29.000 \\
\hline Biaya overhead pabrik & Rp. 2.663.150 & & 2.450 \\
\hline Biaya tenaga kerja & Rp. $10,870,000$ & & 10.000 \\
\hline Jumlah & Rp. 45.056.150 & & 41.450 \\
\hline Harga Pokok Produk Jadi & & Rp. 26. & 03.650 \\
\hline \multicolumn{4}{|l|}{ Harga Pokok Produk dalam Proses } \\
\hline Biaya Bahan Baku (BBB) & Rp. 13.050 .000 & & \\
\hline Biaya Overhead Pabrik (BOP) & Rp. 1.102 .500 & & \\
\hline Biaya Tenaga Kerja Langsung (BTKL) & Rp. 4.500.000 & & \\
\hline Jumlah biaya produk yang dibebankan & & Rp. 18 , & $\underline{52, \underline{500}}$ \\
\hline \multirow[t]{2}{*}{ Jumlah biaya produksi yang dibebankan } & & Rp. 45 & 56,150 \\
\hline & & Kembali & Cetak \\
\hline
\end{tabular}

Gambar 6 Laporan Biaya Produksi untuk Boneka Teddy Bear per Mei 2018

\section{KESIMPULAN DAN SARAN}

\subsection{Kesimpulan}

Berdasarkan hasil pengujian manual dan pengujian aplikasi dengan menggunakan transaksi yang sama, hasil yang didapatkan oleh kedua cara mempunyai nilai yang sama, sehingga dapat disimpulkan bahwa aplikasi ini dapat melakukan perhitungan biaya produksi, harga persatuan, dan harga pokok produksi. Aplikasi juga dapat menyajikan laporan yang berkaitan berupa laporan biaya produksi serta menghasilkan jurnal umum, dan buku besar. 


\subsection{Saran}

Pengembangan penelitian selanjutnya dapat melakukan pembelian secara kredit beserta potongan dan retur pembelian, dan mampu melakukan pengelolaan persediaan bahan baku.

\section{DAFTAR PUSTAKA}

Afif, M., \& Rahmawati, D. (2017). Analisis Perhitungan Harga Pokok Produksi Teh Sedap Wangi Menggunakan Metode Harga Pokok Proses pada PT. Sariwangi A.E.A. Akunida, 3 No. 1, 1-19.

Dermawan, D. (2013). Desain dan Pemrograman. Bandung: PT Raja Rosdakarya.

Indarwati, Kastaman, \& Samiji, I. (2017). Aplikasi Penyusunan Laporan Biaya Produksi Berdasarkan Harga Pokok Proses Berbasis Web (Studi Kasus di CV Triwarna Mulya Indah Kota Bandung), Proyek Akhir, Program Studi D3 Komputerisasi Akuntansi. Bandung: Telkom University.

Irwandi, M. R., Yuniar, I., \& Kotjoprayudi, R. B. (2017). Aplikasi Harga Pokok produksi Dengan Metode Harga pokok Pesanan Dan Harga Pokok Proses (Studi Kasus : PT. Sinar Sakti Matra Nusantara, Bandung, Jawa Barat), Proyek Akhir, Program Studi D3 Komputerisasi Akuntansi. Bandung: Telkom University.

Mulyadi. (2015). Akuntansi Biaya . Yogyakarta: sekolah Tinggi Ilmu Manajemen .

Munifah, M. N., Widayanti, A., \& Yuniar, I. (2016). Aplikasi Perhitungan Biaya Produksi Menggunakan Metode Process Costing Berbasis Web (Studi Kasus di Pabrik Siomay Hade, Ciparay), Proyek Akhir, Program Studi D3 Komputerisasi Akuntansi. Bandung: Telkom University.

Prima, S. (2013). Akuntansi Biaya. In Media.

Riza, K. (2016). Akuntansi Biaya. Jakarta: Indeks.

Samryn, L. (2015). Akuntansi Manajemen. jakarta: Kencana.

Sari, D. I. (2018, Oktober). Perhitungan Harga Pokok Produksi Dengan Metode Harga Pokok Proses Pada PT. Persada. Moneter, 5 No. 2, 163-170.

Sukamto, R. A. (2013). Rekayasa Perangkat lunak. Bandung: Informatika.

Witjaksono, A. (2013). Akuntansi Biaya. Yogyakarta: Graha Ilmu.

Yuniar, D. C., Agung, A. G., \& Abdillah, J. (2016). Aplikasi Perhitungan Harga Pokok Produksi Menggunakan Metode Biaya Proses. Konferensi Nasional Sistem Informasi (pp. 406-411). Batam: LPPM STT Ibnu Sina Batam. 